\title{
Analisis Transaksi Terapeutik Sebagai Sarana Perlindungan Hukum Bagi Pasien
}

\author{
Anggraeni Endah Kusumaningrum \\ Fakultas Hukum, Untag Semarang, Jl. Pemuda No.70, Pandansari, Semarang, 50133 \\ E-mail: anggraeniwijayanto@yahoo.com
}

\begin{abstract}
This paper aims to know and analyze therapeutic transactions as a means of legal protection for patients. Therapeutic transactions are agreements between physicians and patients who authorize the physician to perform activities to provide health services to patients based on the skills and skills possessed by the doctor. The legal relationship in such therapeutic transactions creates rights and obligations that must be obeyed and implemented by each party. This research uses normative juridical approach method with primary data source is secondary data supported by primary data. Primary data is obtained directly through interviews and secondary data in the form of legal materials, both primary, secondary and tertiary which will be analyzed qualitatively through data collecting, data reduction, data presentation and verification of data or conclusions. The results obtained that therapeutic transactions position physicians and patients, on the same relationship with the hope of providing legal protection for the parties, but in fact the norms have not been able to provide legal protection. That happens because there is no arrangement of the implementation of the transaction therapeutic consistently.
\end{abstract}

Keywords - : therapeutic transactions; legal protection.

\section{PENDAHULUAN}

\section{A. Latar Belakang}

Pada awalnya hubungan dokter dan pasien didasarkan pada hubungan paternalistik ${ }^{l}$. Hubungan paternalistik merupakan pola hubungan yang didasarkan karena ada kepercayaan (fiduciary relationship) antara pasien kepada seorang dokter. Artinya pasien yang sakit tersebut pasrah dan menerima apapun yang dilakukan dokter atas tubuhnya demi kesembuhannya. Sikap pasrah ini tercermin dari sikap pasien yang menerima apapun akibat dari pengobatan tersebut, meskipun pasien menjadi cacat atau bahkan meninggal dunia, dan hal itu dianggap sebagai takdir dari Tuhan YMK. Oleh karena itu dulu jarang terdengar pasien atau keluarganya, menyalahkan atau menuntut dokter yang merawatnya.

Seiring dengan perkembangan jaman hubungan dokter dan pasien yang berpola paternalistik berubah menjadi horizontal kontraktual. Hubungan horizontal kontraktual menyebabkan dokter dan pasien mempunyai kedudukan yang sejajar ${ }^{2}$ yaitu bahwa dokter dan pasien sepakat, untuk saling memberi prestasi (dengan berbuat atau tidak berbuat) di bidang pelayanan kesehatan. Dokter dan pasien adalah subjek hukum yang membentuk hubungan medik maupun hubungan hukum dengan objek berupa pemeliharaan kesehatan maupun pengobatan penyakit. Hubungan ini menimbulkan hak dan kewajiban yang harus dipenuhi oleh para pihak. Adanya hak dan kewajiban yang harus dipenuhi oleh para pihak, dan konsekuensinya tentu berupa pertanggungjawaban secara hukum. Oleh karena itu antara dokter dan pasien ada hubungan hukum berupa perjanjian atau persetujuan secara spesifik dan lazim disebut transaksi terapeutik ${ }^{3}$. Transaksi terapeutik mencakup bidang diagnostik, preventif, rehabilitatif, maupun promotif.

${ }^{1}$ Pola hubungan paternalistik, yaitu dokter dianggap akan berupaya semaksimal mungkin untuk menyembuhkan pasien, seperti seorang bapak yang baik yang akan berbuat apa saja untuk kepentingan anaknya. Pasien diharapkan akan bertindak sebagai anak yang patuh dan percaya bahwa dokter akan bertindak sebagai bapak yang baik. Doktrin inilah yang dulu tertanam di dalam pikiran seorang pasien. Pola hubungan vertikal yang melahirkan sifat paternalistik sang pengobat terhadap si sakit ini mengandung baik dampak positif maupun dampak negatif. Dampak positif pola vertikal yang melahirkan konsep hubungan paternalistik ini sangat membantu si sakit dalam hal si sakit awam terhadap penyakitnya. Sebaliknya dapat juga timbul dampak negatif apabila tindakan sang pengobat yang berupa langkah-langkah dalam mengupayakan penyembuhan si sakit itu merupakan tindakantindakan sang pengobat yang membatasi otonomi si sakit, yang menurut sejarah perkembangan budaya dan hak-hak dasar manusia telah ada sejak lahirnya. Hermien Hadijati Koeswadji, 1998, Hukum Kedokteran : studi tentang Hubungan Hukum Dalam Mana Dokter sebagai Salah Satu Pihak, Bandung PT. Citra Aditya Bakti, hlm.37. Pola hubungan demikian diidentik dengan pola hubungan vertikal dimana kedudukan dokter dengan pasien tidak sederajat, pasien menyerahkan nasib sepenuhnya kepada dokter yang merawatnya. James F. Childerss, 1989, Prioritas-prioritas dalam Etika Biomedis, Cetakan Pertama, Penerbit Kanisius, Yogyakarta, hlm.17. Apabila dianalogi ini diterapkan pada pelayanan kesehatan, dokter dipandang sebagai orang tua yang memperlakukan pasien sebagai anak kecil yang tidak diizinkan untuk menentukan kesejahteraannya sendiri ataupun cara pencapaiannya.

${ }^{2}$ Ani Isfandyarie, 2005, Malpraktek \& Resiko Medik dalam Kajian Hukum Pidana, Jakarta, Prestasi Pustaka, hlm.2.

${ }^{3}$ Transaksi terapeutik adalah sebuah kesepakatan yang dilakukan dalam rangka terapi, dalam hal ini terapi yang bukan hanya menyangkut kesehatan saja melainkan juga menyangkut semua aspek kesehatan yaitu menyangkut promotif, preventif, kuratif maupun rehabilitative. Istilah transaksi terapeutik dapat ditemukan dalam Mukadimah Kode Etik Kedokteran Indonesia ( KODEKI ) yang terdapat dalam Keputusan Menteri Kesehatan RI Nomer 434/Men.Kes/X/1983 tentang berlakunya Kode Etik Kedokteran Indonesia yang mencantumkan tentang transaksi terapeutik sebagai berikut: yang diimaksud dengan transaksi terapeutik adalah hubungan hukum antara dokter dan penderita yang dilakukan dalam suasana saling percaya 
Saat ini dengan meningkatnya kesadaran masyarakat akan hak-hak yang mereka miliki sebagai pasien, maka pemahaman tersebut membuat pasien tidak lagi bersikap pasif menunggu dan mengiyakan tindakan pemeriksaan dan pengobatan apapun yang diberikan dokter kepadanya, namun pasien ikut serta menentukan apa yang terbaik bagi tubuhnya, sekalipun pemahaman pasien tersebut sering kali tidak direspon oleh dokter sehingga muncul konflik dan berujung pada sengketa medik antara keduanya.

Berdasarkan pengamatan penulis ada beberapa kasus-kasus pengabaian maupun pengingkaran hak pasien yang pernah diberitakan media (baik surat kabar, majalah, maupun televisi) antara lain kasus antara:

1. Marzuki dan Herawati, anak dan istri Hilyadi di Lampung Tengah mengadukan dokter karena mengakibatkan Hilyadi meninggal dunia setelah mendapatkan suntikan di Rumah Sakit Harapan Bunda Gunung Sugih Lampung Tengah. ${ }^{4}$

2. Ratna Suminar mengadukan sebuah Rumah Sakit di Kota Cimahi Jawa Barat karena anaknya yang bernama Sepia Rizkiani 18 bulan mengalami kebutaan setelah mendapat infus di kening, padahal Ratna menolak pemasangan infus tersebut pada saat anaknya dirawat. ${ }^{5}$

3. Harun, 35 tahun warga Bogor Jawa Barat mensomasi dokter dan rumah sakit karena melakukan operasi dengan tidak hatihati dan ceroboh ${ }^{6}$.

4. Keluarga almarhum Wagiman Riyanto (60 tahun), yang mengadukan Rumah Sakit Daerah dr. Sobandi Jember karena tidak mau memberi penjelasan atas meninggalnya Wagiman.

5. FM (15 tahun) warga Banyumas mengadukan seorang dokter yang menyunatnya dengan ceroboh sehingga FM harus kehilangan alat vitalnya sepanjang 5 centimeter. $^{8}$

6. Keluarga almarhum Robinson Sitorus warga Pematang Siantar Sumatera Utara, yang mengadukan seorang dokter karena salah memberikan obat diabetes meskipun sudah diingatkan bahwa pasien tidak biasa mengkonsumsinya. ${ }^{9}$

7. Dokter diadukan karena melakukan amputasi (pemotongan) jari telunjuk seorang bayi akibat pemasangan infus yang salah dan tanpa ada persetujuan tindakan medik. ${ }^{10}$

Berdasarkan kasus -kasus diatas maka perumusan masalah dalam tulisan ini adalah :

a. Bagaimanakah pengaturan hak dan kewajiban dalam transaksi terapeutik antara dokter dan pasien menurut hukum positif di Indonesia?

b. Faktor-faktor apasajakah yang menjadi penyebab transaksi terapeutik antara dokter dan pasien belum dapat memberikan perlindungan hukum?

\section{B. Metode Penelitian}

Jenis penelitian yang digunakan dalam penelitian ini adalah metode penelitian hukum normatif, yaitu penelitian hukum yang meletakkan hukum sebagai sebuah bangunan sistem norma. Sistem norma yang dimaksud adalah mengenai asas-asas, norma, kaidah dari peraturan perundang-undangan serta doktrin. Dalam penelitian ini dipergunakan metode pendekatan yuridis, dengan meneliti kaidah atau aturan hukum sebagai suatu bangunan sistem yang terkait dengan suatu peristiwa hukum. ${ }^{11}$ Jenis data yang digunakan dalam penelitian ini adalah Data Sekunder yang terdiri dari Bahan Hukum Primer, Bahan Hukum Sekunder, dan bahan Hukum Tertier yang diperoleh dari buku-buku, literatur, makalah, peraturan perundang-undangan dan sumber data lain. Pengumpulan data sekunder dilakukan menggunakan metode pendekatan literatur, yaitu suatu penelitian kepustakaan dengan menggunakan bahan-bahan pustaka hukum yang mendukung dalam penelitian ini. Pengumpulan bahan-bahan hukum dilakukan dengan cara penelusuran, pengumpulan, dan studi dokumen secara konvensional seperti membaca, melihat mendengarkan, maupun dengan teknologi informasi (media internet). Data sekunder yang berupa bahan hukum primer, bahan hukum sekunder, dan bahan hukum tertier yang telah dikumpulkan dan diolah akan dianalisis dengan metode normatif yang kemudian akan disajikan secara deskriptif. Analisis data dalam penelitian ini dipergunakan analisis kualitatif.

\section{HASIL PENELITIAN DAN ANALISIS PEMBAHASAN}

\section{A. Pengertian transaksi terapeutik}

Dalam kamus besar Bahasa Indonesia persetujuan diartikan juga sebagai “transaksi”.Transaksi terapeutik adalah persetujuan yang terjadi antara dokter dan pasien dibidang pengobatan (sesuatu yang mengandung unsur atau nilai pengobatan) yang mencakup bidang diagnostik, preventif, rehabilitatif, maupun promotif. Transaksi terapeutik tersebut timbul sebagai akibat dari adanya hubungan horizontal kontraktual. Transaksi terapeutik secara yuridis diartikan sebagai hubungan hukum antara dokter dengan pasien dalam pelayanan medis secara profesional dengan didasarkan pada kompetensi yang sesuai pada keahlian

( konfidensial ) serta senantiasa diliputi oleh segala emosi, harapan dan kekhawatiran mahluk insani. Oleh karena itu bersifat menjelaskan, memerinci ataupun menegaskan berlakunya suatu kode etik untuk melindungi dokter dan pasien.

${ }^{4}$ Kompasiana, 04/10/12 . diakses pada tanggal 14 juni 2015

${ }^{5}$ Tempo.com , 18 Agustus 2014 , jam 05.45, diakses pada tanggal 14 Juni 2015

${ }^{6}$ Tempo.com, 30 Mei 2014, jam 14.34, diakses pada 14 Juni 2015

${ }^{7}$ Tempo.com, 3 Desember 2013, jam 19.37, diakses pada 14 Juni 2015

${ }^{8}$ Tempo.com, 28 November 2013, jam 15.51, diakses pada 14 Juni 2015

${ }^{9}$ Indosiar.com, 10 Pebruari 2014, jam 19.37, diakses pada 14 Juni 2015

${ }^{10}$ Indosiar.com, 10 April 2013, diakses pada 14 Juni 2015

${ }^{11}$ Mukti Fajar dan Yulianto Achmad, 2010, Dualisme Penelitian Hukum Normatif \& Empiris, Cetakan I, Pustaka Pelajar, Yogyakarta, hal. 36 
dan keterampilan tertentu di bidang kesehatan. Transaksi terapeutik itu dikategorikan sebagai perjanjian yang diatur dalam ketentuan Pasal 1601 Bab 7A Buku III KUH Perdata, yaitu termasuk jenis perjanjian untuk melakukan jasa yang diatur dalam ketentuan khusus. Ketentuan khusus yang dimaksudkan adalah Undang-Undang Nomor 36 Tahun 2009 Tentang Kesehatan. Selain itu, jika dilihat ciri yang dimilikinya yaitu pemberian pertolongan yang dapat dikategorikan sebagai pengurusan urusan orang lain (zaakwaarnerning) yang diatur dalam Pasal 1354 KUH Perdata, maka transaksi terapeutik merupakan perjanjian ius generis. Adapun yang dimaksud dengan perjanjian pemberian jasa, yaitu suatu perjanjian di mana pihak yang satu menghendaki pihak lawannya melakukan suatu pekerjaan untuk mencapai suatu tujuan dengan kesanggupan membayar upahnya, sedangkan cara yang akan dilakukan untuk mencapai tujuan tersebut diserahkan pada pihak lawannya. Pihak lawan tersebut adalah seorang ahli dalam bidangnya dan telah memasang tarif untuk jasanya. ${ }^{12}$

\section{B. Pengaturan Transaksi Terapeutik Antara Dokter Dan Pasien Menurut Hukum Positif Di Indonesia}

Sekalipun transaksi terapeutik dikategorikan sebagai perjanjian pemberian jasa, namun didasarkan perkembangannya merupakan hubungan pelayanan atas kepercayaan, dan didasarkan prinsip pemberian pertolongan, sehingga disebut sebagai hubungan pemberian pertolongan medis. berdasarkan prinsip pemberian pertolongan ini, maka dokter tidak dibenarkan memberikan pertolongan rnedis melebihi kebutuhan dari orang yang ditolong, karena pemberian pertolongan bertujuan untuk memulihkan kemampuan orang untuk dapat mengatur dirinya sebaik-baiknya, sehingga pelayanan medis yang diberikannya kepada pasien harus berorientasi demi kepentingan pasien. Sementara itu pada pihak pasien prinsip pemberian pertolongan berarti pasien sebagai penerima pertolongan tidak dapat melepaskan tanggung jawab atas dirinya seluruhnya atau pasrah kepada dokter sebagai pemberi pertolongan yang memiliki kemampuan profesional di bidang medis. ${ }^{13}$

Berdasarkan hal tersebut maka Tujuan Transaksi Terapeutik adalah :1). Menyembuhkan dan mencegah penyakit, pemberi Pelayanan kesehatan berkewajiban untuk memberikan bantuan Pelayanan kesehatan yang dibatasi oleh kriterium memiliki kemampuan untuk menyembuhkan dan dapat mencegah atau menghentikan proses penyakit yang bersangkutan. Sebagaimana diatur Pasal 53 Undang-Undang Nomor 36 Tahun 2009 bahwa tenaga kesehatan dalam menjalankan profesinya bertugas menyelenggarakan atau melakukan kegiatan kesehatan sesuai dengan bidang keahlian dan atau kewenangannya. Untuk menjamin terselenggaranya kegiatan tersebut, maka setiap tenaga kesehatan termasuk dokter berhak memperoleh perlindungan hukum, sepanjang yang dilakukannya sesuai dengan standar profesi dan tidak melanggar hak pasien/klien. Dengan demikian standar profesi sebagai pedoman yang harus digunakan sebagai petunjuk dalam menjalankan profesi secara baik, sebenarnya merupakan penyelenggaraan otonomi professional kesehatan dan sekaligus merupakan pembatasan dalam menjalankan profesi. Standar profesi yang dimaksud di atas adalah standar Pelayanan kesehatan yang disusun oleh masing-masing asosiasi profesi kesehatan seperti IDI, PDGI, PPNI, IBI, IFI dan asosiasi profesi kesehatan lainnya. Standar profesi tersebut dapat dirumuskan sebagai cara bertindak dalam peristiwa yang nyata berdasarkan ilmu pengetahuan dan pengalaman.2). Meringankan penderitaan, artinya bahwa tindakan medik yang dilakukan dalam penyembuhan penyakit dan pemulihan kesehatan pasien harus secara nyata ditujukan untuk memperbaiki keadaan pasien atau agar keadaan kesehatan pasien lebih baik dari sebelumnya, maka guna meringankan penderitaan pasien, penggunaan metode diagnostik atau terapeutik yang lebih menyakitkan seharusnya dihindarkan. Pemberian bantuan atau pertolongan untuk meringankan penderitaan ini merupakan bagian dari suatu tugas pemberi Pelayanan kesehatan professional, sehingga berlaku standar Pelayanan kesehatan yang didasarkan pada ketelitian dan sikap berhati-hati. Di dalam pengertian upaya kesehatan terlihat bahwa kegiatan yang dilakukan adalah untuk memelihara dan meningkatkan kesehatan, oleh karena itu dalam pengertian upaya meringankan penderitaan atau mengurangi perasaan sakit, termasuk juga menghindarkan penderitaan yang diakibatkan oleh upaya perawatan kesehatan. Secara yuridis apabila dokter/terapis tidak memenuhi kewajibannya dengan berbuat sesuatu yang meringankan atau mengurangi perasaan sakit, sehingga menimbulkan kerugian fisik ataupun non fisik pada pasien, maka dokter dan atau tenaga kesehatan yang bersangkutan dapat dituntut penggantian kerugian ( Pasal 58 Undang-undang Nomor 36 Tahun 2009 ). 3 ). Mendampingi pasien. Di dalam pengertian ini termasuk juga mendampingi menuju kematiannya. Kegiatan mendampingi pasien ini seharusnya sama besar dengan kegiatan untuk menyembuhkan pasien. Sehubungan dengan hal tersebut seringkali tidak terpenuhinya kegiatan untuk meringankan penderitaan dan untuk mendampingi pasien dipersalahkan karena kurang atau tidak adanya waktu yang tersedia. Sekalipun kegiatan teknis medis dapat merupakan Pelayanan yang baik terhadap pasien, namun hukum mewajibkan seorang dokter atau tenaga kesehatan selaku professional untuk melakukan baik kegiatan pemberian pertolongan maupun kegiatan teknis medik sesuai dengan waktu yang tersedia dengan mematuhi standar profesi dan menghormati hak pasien/klien.

\section{Faktor-Faktor Penyebab Transaksi Terapeutik Antara Dokter Dan Pasien Belum Dapat Memberikan Perlindungan Hukum}

Transaksi terapeutik sebenarnaya memposisikan kedudukan dokter dan pasien, pada hubungan yang sederajat. Kondisi tersebut terlihat dari banyaknya peraturan perundang-undangan yang mengaturnya, mulai dari undang-undang ( Undang Undang No. 29 Tahun 2004 tentang Praktik Kedokteran, Undang Undang No 36 Tahun 2009 tentang Kesehatan dan Undang Undang No. 44 Tahun 2009 tentang Rumah Sakit ), ( PP NomorTahun 1960 tentang Wajib Simpan Rahasia Kedokteran)

\footnotetext{
${ }^{12}$ Veronica Komalawati, Peranan Informed Consent dalam Transaksi Terapeutik, Op.cit., hal.140

${ }^{13}$ Ibid, hal. 141
} 
hingga peraturan yang berbentuk tekhnis yang diatur di dalam Peraturan /Keputusan Menteri Kesehatan (Permenkes Nomor.269 Tahun 2008 tentang Rekam Medik, Permenkes Nomor. 290 Tahun 2008 tentang Persetujuan Tindakan Kedokteran, PerMenKes Nomor 2052/MENKES/PER/X/2011 tentang Izin Praktik dan Pelaksanaan Praktik Kedokteran). Begitu banyak norma yang mengatur tentang transaksi terapeutik tersebut dengan harapan dapat memberikan perlindungan hukum bagi para pihak, namun pada kenyataannya norma-norma tersebut belum dapat memberikan perlindungan hukum.Hal itu terjadi disebabkan karena belum adanya pengaturan pelaksanaan transaksi terapeutik secara konsisten. Dalam arti para pihak menyadari dan mengetahui kedudukan dan posisinya masing-masing, sebab masih banyak dokter yang tidak memahami bahwa transaksi terapeutik menimbulkan adanya hubungan hukum antara dokter pasiennya sehingga akibatnya dokter menganggap bahwa pasien adalah objek bukan subjek dalam pelayanan medik. Selain itu saat ini belum dapat tercipta secara baik adanya komunikasi dua arah antara dokter dan pasien, untuk saling memberi informasi yang dibutuhkan dan diperlukan agar dapat memberikan pengobatan dan mendapatkan pengobatan yang diharapkan.

Faktor faktor penyebab transaksi terapeutik saat ini belum dapat memberikan perlindungan hukum bagi pasien yang terdapat pada substansi, struktur maupun budaya hukumnya, sebagaimana penjelasan dibawah ini:

Secara substansi hukum ada aturan maupun norma yang saling berbenturan satu sama lain, ataupun peraturan tersebut tidak jelas ( kabur ). Selain itu juga terdapat hal-hal penting yang belum atau tidak diatur dalam hukum kesehatan. Hal diatas terakumulasi sehingga terjadi banyak peraturan-peraturan yang tidak jelas. Persoalan tersebut tentu akan menimbulkan ambiguitas dan ketidakpastian hukum,

\section{a) Benturan Hukum}

Sebagaimana kita ketahui terdapat banyak norma hukum yang berlaku dalam penyelenggaraan praktik kedokteran. Norma tersebut idealnya diabdikan untuk dapat mengakomodir kebutuhan sekaligus melindungi kepentingan para pihak dalam pelayanan kesehatan, khsusunya dokter dan pasien sehingga dapat memberikan keadilan, kepastian maupun kemanfaatan bagi masyarakat. Kenyataannya, ada norma hukum yang berbenturan seperti pada pasal 4 ayat 1 dan ayat 2 Permenkes No. 2052 tahun 2011 Tentang izin praktek dan pelaksanaan praktik kedokteran terkait Surat Ijin Praktik (SIP) dokter dan dokter spesialis diberikan paling banyak untuk tiga ( 3 ) tempat praktik baik pada fasilitas pelayanan kesehatan milik pemerintah, swasta, maupun praktik perseorangan. Namun dalam pasal 6 Permenkes yang sama mengatur bahwa guna melaksanakan program pemerataan pelayanan kesehatan SIP dokter berlaku juga bagi fasilitas pelayanan kesehatan pemerintah dalam wilayah binaannya yang tidak memiliki dokter,artinya karena pemerataan pelayanan kesehatan, maka seorang dokter diperbolehkan menggunakan SIP di wilayah binaannya meskipun dokter tersebut sudah memiliki 3 (tiga) tempat praktik. Ironisnya, berdasarkan pasal 37 ayat 3 Undang-Undang Nomer 29 Tahun 2004 tentang Praktik Kedokteran dan pasal 10 ayat 2 Permenkes No 2052 Tahun 2011 menyatakahn bahwa satu Surat Ijin Praktik hanya berlaku untuk 1 (satu) tempat praktik. Mencermati hal tersebut jelaslah bahwa pasal 6 Permenkes 2052 tahun 2011 ini berpotensi menimbulkan ketidakpastian.

b) Kevakuman Hukum

Pasal 19 Permenkes RI, Nomor 290/Men.Kes/Per/III/2008 yang menyatakan bahwa dalam rangka pembinaan dan pengawasan persetujuan tindakan kedokteran kepada dokter tersebut dapat diberikan sanksi administrasi berupa teguran lisan, teguran tertulis, sampai dengan pencabutan surat izin praktek. Adanya ketentuan yang mengatur mengenai pemberian sanksi administrasi ini menjadi penting untuk menunjukkan bahwa telah ada ketentuan yang mengatur informed consentper se. Artinya sanksi tetap dapat diberikan sekalipun mungkin tindakan medik yang telah dilakukan tidak menimbulkan bahaya apapun bagi pasien yang telah dirawatnya. Sebaliknya tanpa adanya ketentuan yang mengatur sanksi akan menunjukkan bahwa kewajiban meminta informed consent seakan-akan hanya sebagai upaya melindungi profesi dokter ketika mengalami kegagalan dalam tindakan mediknya.Namun disayangkan ternyata dalam permenkes tersebut tidak ada penjelasan lebih lanjut mengenai hal pelanggaran tindakan kedokteran seperti apa dan bagaimana yang akan mendapatkan sanksi administrasi.

Selanjutnya berkaitan dengan penolakan tindakan kedokteran meskipun dalam pasal 16Permenkes Nomor 290/Men.Kes/Per/III/2008 mengatur tentang penolakan pasien terhadap tindakan kedokteran setelah pasien tersebut menerima penjelasan tentang tindakan kedokteran yang akan dilakukan maupun tatacara penolakan tindakan kedokteran tersebut, namun muncul permasalahan lain yang belum diatur dalam peraturan perundang-undangan. Masalah tentang informed consentyang belum ada pengaturannya adalah: apakah informed consent yang telah diberikan oleh pasien dapat dicabut atau ditarik kembali oleh pasien, batas-batasdiperbolehkannya informed consent itu dicabut atau ditarik. Informed consent merupakan wujud otonomi dari individu yang memberikannya. Informed consent diberikan secara sepihak, artinya tidak ada kewajiban baik dari perjanjian maupun dari undang-undang bagi pasien untuk memberikannya. Oleh karena itupemberian informed consent merupakan hak, bahkan hak mutlak pasien. Terhadap hak mutlak ini tidak ditemukan pembatasan penggunaannya. Dalam hal ini patut dikemukakan pendapat yang menyatakan apabila tidak dapat dicabut, maka hal itu merupakan ketidak adilan, sebab informed consent sangat berkaitan dengan fisik manusia yang sedemikian fundamental kepentingannya sebagai identitas dan otonomi seseorang. Sehingga seharusnya informed consent dapat dicabut sewaktu-waktu dan pada tahap apapun tanpa berunding dengan pihak yang telah menerimanya sepanjang belum menimbulkan akibat hukum yang nyata.

Demikian pula mengenai pengaturan Pasal 21 ayat (1) Permenkes No 2052/Menkes/Per/X/2011 tentang Izin Praktik dan Pelaksanaan Praktik Kedokteran menyebutkan bahwa "Praktik kedokteran dilaksanakan berdasarkan pada kesepakatan berdasarkan hubungan kepercayaan antara dokter dan dokter gigi dengan pasien dalam upaya pemeliharaan kesehatan, 
pencegahan penyakit, peningkatan kesehatan, pengobatan penyakit dan pemulihan kesehatan," kemudian pada ayat (2) menyebutkan bahwa kesepakatan yang dimaksudkan ayat (1) merupakan upaya maksimal pengabdian profesi kedokteran yang harus dilakukan dokter dan dokter gigi dalam penyembuhan dan pemulihan kesehatan pasien sesuai dengan standar pelayanan, standar profesi, standar prosedur operasional dan kebutuhan medis pasien, upaya maksimal sebagaimana dimaksud ayat 2 sesuai dengan situasi dan kondisi setempat. Pasal 21 ayat 2 Permenkes No 2052/Menkes/Per/X/2011 tentang Izin Praktik dan Pelaksanaan Praktik Kedokteran ini merupakan kewajiban dokter dalam penyelenggaraan praktik kedokteran yang harus sesuai dengan standar pelayanan, standar profesi, standar prosedur operasional dan kebutuhan medis pasien, namun sayangnya sampai saat ini belum ada pengaturan standar pelayanan medis ( SPM ) yang berlaku secara nasional, sehingga akibatnya sampai saat ini belum ada standart yang sama terhadap penanganan suatu penyakit, dalam arti dokter maupun rumah sakit menggunakan standartnyasendiri-sendiri sesuai dengan kemampuannya. Hal ini tentu berpotensi dapat menimbulkan kerugian kepada pasien.

c) Kekaburan Hukum

1) Adanya Kesepakatan dalam hubungan dokter dan pasien, merupakan langkah untuk menyesuaikan kehendak maupun kepentingan para pihak. Kepentingan itu tertuang dalam hak dan kewajiban. Hak pasien adalah hak asasi yang bersumber dari hak dasar individu dan hak dasar sosial. Dua asas hukum yang melandasi hukum kesehatan yaitu the right to health care atau hak atas pelayanan kesehatan dan the right ofself determination atau hak untuk menentukan nasib sendiri merupakan hak dasar atau hak primer dalam bidang kesehatan khususnya hukum kedokteran. Pengakuan hak pasien tersebut diatur dalam Permenkes No 290/2008 tentang informed consent dan Permenkes No.269/2008 Rekam Medis . Hak-hak ini semakin mendapat aktualisasinya dengan diundangkannya UU No 36 Tahun 2009 tentang Kesehatan, UU No 44 Tahun 2009 tentang Rumah Sakit dan Sehingga meskipun Undang-undang Nomor 29 Tahun 2004 tentang Praktik Kedokteran

Hak pasien yang bersifat sosial (the right to health care) dirumuskan di dalam Pasal 4 Undang-undang Nomor 36 Tahun 2009 tentang Kesehatan menyebutkan bahwa "Setiap orang berhak atas kesehatan".Konsep hak atas kesehatan ini merujuk pada makna hak untuk memperoleh pelayanan kesehatan dari fasilitas kesehatan agar dapat mewujudkan derajat kesehatan yang setinggi-tingginya. Konsep ini sejalan dengan prinsip theright to health care yang diakui di dalam Deklarasi Universal Hak Asasi Manusia serta Kovenant Internasional tentang hak-hak ekonomi, sosial dan budaya yang merupakan landasan pengakuan dan perlindungan hak-hak asasi manusia secara universal. Pengakuan bahwa hak atas kesehatan adalah bagian dari hak asasi pun dinyatakan di dalam Penjelasan Umum UU Nomor 36 Tahun 2009. Pengakuan ini melahirkan tanggung jawab bagi pemerintah/negara untuk mewujudkan hal tersebut, artinya pemerintah/ negara bertanggung jawab menyediakan berbagai fasilitas kesehatan sesuai tingkat kebutuhan masyarakat / warga negara dalam rangka memenuhi hak setiap orang/warga negara untuk mendapatkan pelayanan kesehatan. Termasuk dalam hal itu adalah perlindungan hak-hak atas kesehatan yang bersifat individual.

Berbeda dengan hak yang bersifat sosial dimana pemenuhannya langsung menjadi tanggung jawab negara, maka hak kesehatan yang bersifat individu pemenuhannya akan bergantung pada pihak kedua, yang dalam konteks hak pasien ini maka tuntutan pemenuhannya ada pada dokter. Selanjutnya berkaitan dengan Pasal 4 Undang-undang Nomor 36 Tahun 2009 tentang Kesehatan menyebutkan bahwa " setiap orang berhak atas kesehatan ", dari rumusan itu dapat diartikan bahwa setiap orang mempunyai hak untuk menentukan sendiri pelayanan kesehatan yang dibutuhkan, serta mempunyai hak untuk memperoleh informasi atas kesehatan dirinya. Hak yang terdapat dalam Pasal 4 Undang Undang Kesehatan tersebut kemudian mendapat penguatan norma melalui Pasal 56 dan Pasal 57 Undang Undang Nomor 36 Tahun 2009 tentang Kesehatan, yang mengatur mengenai perlindungan pasien ${ }^{14}$. Berdasarkan hal tersebut ternyata Undang-undang Nomor 36 tentang Kesehatan memberikan perumusan yang berbeda terhadap hak yang dimiliki setiap orang di bidang kesehatan ketika berada dalam kedudukan sebagai pasien, bahkan meskipun judul dari paragraf kedua dalam Undangundang Nomor 36 tentang Kesehatan adalah perlindungan pasien, namun isinya sama sekali tidak mengatur mengenai perlindungan kepada pasien. Demikian pula dalam Pasal 3 Undang Undang No 29 Tahun 2004 tentang Praktik Kedokteran yang menyatakan bahwa pengaturan praktik kedokteran bertujuan untuk: a. memberikan perlindungan kepada pasien. b. Mempertahankan dan meningkatkan mutu pelayanan medis yang diberikan oleh dokter dan dokter gigi; c. memberikan kepastian hukum kepada masyarakat, dokter dan dokter gigi. Namun baik dalam Undang Undang Nomor 36 Tentang Kesehatan dan Undang Undang Nomor 29 Tahun 2004 tentang Praktik Kedokteran dalam penjelasannya tidak memberikan penjelasan lebih lanjut mengenai apa yang dimaksud dengan perlindungan pasien. Dalam penjelasan ke dua undang undang tersebut hanya ada kata-kata "sudah jelas", berkaitan dengan hal itu tentunya dapat menimbulkan kerancuan, dan berujung pada tidak adanya kepastian hukum.

${ }^{14}$ Periksa Pasal 56 dan Pasal 57 Undang Undang Nomor 36 Tahun 2009 tentang Kesehatan, dalam Pasal 56 ayat 1 yang menyatakan bahwa setiap orang berhak menerima atau menolak sebagian atau seluruh tindakan pertolongan yang akan diberikan kepadanya setelah menerima dan memahami informasi mengenai tindakan tersebut secara lengkap, sedangkan ayat 2 menyatakan bahwa hak menerima atau menolak sebagaimana dimaksud ayat 1 tidak berlaku pada : a. penderita penyakit yang penyakitnya dapat secara cepat menular kedalam masyarakat yang lebih luas; b. keadaan seseorang yang tidak sadarkan diri, atau, c. ganguan mental berat. Ayat 3 menyatakan bahwa ketentuan mengenai hak menerima atau menolak sebagaimana dimaksud pada ayat (1) diatur sesuai dengan ketentuan peraturan perundangan. Pasal 57 ayat 1 menyatakan bahwa setiap orang berhak atas rahasia kondisi kesehatan pribadinya yang telah dikemukakan kepada penyelenggara pelayanan kesehatan, sedangkan ayat 2 menyatakan ketentuan mengenai hak atas rahasia kondisi kesehatan pribadi sebagaimana dimaksud pada ayat 1 tidak berlaku dalam hal : a. perintah undang- undang, b. perintah pengadilan,c. izin yang bersangkutan; d. kepentingan masyarakat; e. kepentingan orang tersebut. 
2) Transaksi terapeutik yang mendasari adanya hubungan antara dokter dan pasien yang dimulai dari adanya pemilihan dokter oleh seorang pasien untuk menyembuhkan sakit yang dideritanya. Pemilihan dokter ini menunjukan adanya penundukan diri secara sukarela seorang pasien terhadap dokter yang sudah dia pilih yang dilanjutkan dengan penerimaan ataupun kesediaan dokter untuk mengobati pasien tersebut. Pasal 39 UU No 29 Tahun 2004 menyatakan bahwa praktik kedokteran diselenggarakan berdasarkan pada kesepakatan antara dokter atau dokter gigi dengan pasien dalam upaya untuk pemeliharaan kesehatan, pencegahan penyakit, peningkatan kesehatan, pengobatan penyakit dan pemulihan kesehatan, dari rumusan tersebut menurut Sabir Alwi ${ }^{15}$ tidaklah tepat, karena berdasarkan pasal 1320 BW/ KUHPerdata hubungan keperdataan dapat terjadi bila para pihak mampu menyatakan kehendaknya, sementara itu dalam hubungan antara dokter dan pasien hanya didasarkan pada kesepakatan dalam arti pasien mampu menyatakan kehendaknya padahal kadang juga terjadi dalam hubungan pasien dengan dokter, pasien dalam kondisi tidak mampu untuk memberikan partisipasi/ kehendaknya.

Selanjutnya Pasal 39 Undang Undang No 29 Tahun 2004 tentang Praktik Kedokteran yang menyebutkan bahwa" Praktik kedokteran diselenggarakan berdasarkan pada kesepakatan antara dokter atau dokter gigi dengan pasien dalam upaya untuk pemeliharaan kesehatan, pencegahan penyakit, peningkatan kesehatan, pengobatan penyakit dan pemulihan kesehatan." Namun sayangnya penjelasan lebih lanjut dari pasal tersebut tidak ada, kemudian pengaturan adanya kesepakatan dalam praktik kedokteran dapat ditemukandalam Pasal 21 ayat (1) Permenkes No 2052/Menkes/Per/X/2011 tentang Izin Praktik dan Pelaksanaan Praktik Kedokteran menyebutkan bahwa " Praktik kedokteran dilaksanakan berdasarkan pada kesepakatan berdasarkan hubungan kepercayaan antara dokter dan dokter gigi dengan pasien dalam upaya pemeliharaan kesehatan, pencegahan penyakit, peningkatan kesehatan, pengobatan penyakit dan pemulihan kesehatan," kemudian pada ayat (2) menyebutkan bahwa kesepakatan yang dimaksudkan ayat (1) merupakan upaya maksimal pengabdian profesi kedokteran yang harus dilakukan dokter dan dokter gigi dalam penyembuhan dan pemulihan kesehatan pasien sesuai dengan standar pelayanan, standar profesi, standar prosedur operasional dan kebutuhan medis pasien, upaya maksimal sebagaimana dimaksud ayat 2 sesuai dengan situasi dan kondisi setempat. Namun demikian ayat 2 Permenkes tersebut sama sekali tidak menyebutkan pengertian lebih lanjut apa yang dimaksudkan dengan “upaya maksimal"dalam penyelenggaraan praktik kedokteran yang akan dilakukan tersebut, sehingga hal ini tentunya akan menimbulkan kerancuan dalam pelaksanaannya.

3) Berkaitan dengan hal kepemilikan rekam medis, sebagaimana diketahui bahwa Undang-undang telah mewajibkan dokter dan rumah sakit untuk melakukan rekam medis atas semua hal yang berhubungan dengan kondisi kesehatan seorang pasien. Hal ini berarti segala sesuatu yang disetujui atau ditolak pasien terkait tindakan medis terhadap dirinya, termasuk pemberian berbagai obat-obatan, merupakan bagian dari hal yang harus dirahasiakan dokter dari pihak ketiga yang tidak berwenang untuk mengetahui dan tanpa seijin pasien. Pemahaman ini melahirkan implikasi hukum bahwa berkas rekam medis yang diselenggarakan oleh health providers merupakan milik dokter/Rumah Sakit namun isi rekam medis merupakan milik pasien, sehingga pihak dokter/RS tidak diperkenankan untukmenghalangi-halangi keinginan pasien yang meminta isi rekam medis untuk kepentingan diri pasien itu sendiri. Oleh karena itu hak ini cenderung disebut dengan hak inzage rekam medis atau hak akses terhadap isi (hak untuk melihat) rekam medis dan bukan hak terhadap berkas rekam medis itu sendiri.Kondisi ini yang masih sering ditemukan kesalahpahaman antara dokter/RS dengan pihak pasien. Di satu sisi pasien menganggap rekam medis adalah miliknya karena berisikan segala informasi tentang kesehatan dirinya yang hanya boleh diketahui orang lain (pihak ketiga) dengan seijin dirinya sehingga ia dapat meminta dan memperoleh rekam medis tersebut ketika ia menghendaki. Namun di sisi lain, pihak dokter/RS pun beranggapan bahwa rekam medis adalah milik fasilitas kesehatan yang bersifat rahasia sehingga tidak boleh dibaca/diketahui oleh pihak luar selain dokter yang merawat atau tenaga kesehatan tertentu yang telah diberi kewenangan untuk itu.Olehkarena itu penulis menganggap perlu untuk memahami makna sebenarnya dari sebuah rekam medis, pihak-pihak yang berwenang dan hak serta kewajiban yang melingkupi pihak-pihak tersebut agar tidak terulang sengketa medis yang bermula dari masalah rekam medis.

Berkaitan dengan isi rekam medis ini sebagai dasar hukum terhadap hal tersebut diatur dalam ketentuan Pasal 47 ayat 1 Undang-undang Nomor 29 Tahun 2004 tentang Praktik Kedokteran menyebutkan bahwa dokumen rekam medis merupakan milik dokter, dokter gigi atau sarana pelayanan kesehatan, sedangkan isi rekam medis merupakan milik pasien. Namun demikian dalam Pasal 12 ayat 3 Permenkes Nomor 269 Tahun 2008 tentang Rekam Medis menyebutkan bahwa pasien hanya berhak untuk mendapatkan isi ringkasannya saja dari rekam medik itu, bukan isinya secara keseluruhan sebagaimana ketentuan pasal 47 ayat 1 Undang-undang Nomor 29 Tahun 2004 tentang Praktik Kedokteran. Pengaturan yang demikian, tentunya menimbulkan permasalahan hukum tersendiri,sebab pasien tentunya akan berpegang pada ketentuan Undang-undang Praktik Kedokteran sebagai peraturan yang tertinggi mengenai kepemilikan isi rekam medis, sedangkan Rumah Sakit akan berpegang pada Permenkes sebagai peraturan pelaksanaannya. Sementara itu di dalam norma hukum terdapat asas preferensi hukum yang menyatakan bahwa peraturan yang lebih tinggi akan mengalahkan peraturan yang lebih rendah ( lex superiori derogat legi inferiori ). Salah satu contoh kasus penolakan pemberian isi rekam medis adalah kasus Prita Mulyasari yang minta isi Rekam Medisnya tapi ditolak pihak Rumah Sakit Omni Internasional, sehingga berujung di Pengadilan.

\footnotetext{
15 Wawancara dengan Dr Sabir Alwi SH.MH, wakil ketua MKDKI Pusat pada tanggal 19 Agustus 2015 jam 10.00.
} 
4) Pasal 58 UU Nomor 36 Tahun 2009 menyebutkan bahwa "setiap orang berhak menuntut ganti rugi terhadap seseorang, tenaga kesehatan, dan/atau penyelenggara kesehatan yang menimbulkan kerugian akibat kesalahan atau kelalian dalam pelayanan kesehatan yang diterimanya", sementara penjelasan pasal tersebut hanya menyatakan bahwa yang dimaksud dengan " kerugian " adalah tindakan akibat pelayanan kesehatan termasuk di dalamnya adalah pembocoran rahasia kedokteran, tetapi mengenai kemana tuntutan kerugian tersebut akan diajukan sama sekali tidak diatur. Selanjutnya dalam ketentuan Pasal 66 Undang-undang Nomor 29 Tahun 2004 tentang Praktik Kedokteran menyebutkan bahwa, setiap orang yang mengetahui atau kepentingannya dirugikan atas tindakan dokter/dokter gigi “ dapat " mengadukan secara tertulis kepada Ketua Majelis Kehormatan Disiplin Kedokteran Indonesia (MKDKI) ( ayat 1 ), dimana pengaduan sebagaimana dimaksud tidak menghilangkan hak setiap orang untuk melaporkan adanya dugaan tindak pidana kepada pihak yang berwenang dan/atau menggugat kerugian ke pengadilan ( ayat 3 ).Apabila dicermati konstruksi pasal 66 ayat 3 Undang- Undang Nomor 29 Tahun 2004 tentang Praktik Kedokteran maka,masih memungkinkan dan terbuka peluang bagi pasien yang merasa dirugikan selain mengadu ke Majelis Kehormatan Disiplin Kedokteran Indonesia ( MKDKI ), sekaligus juga memberi hak untuk mengadukannya baik secara perdata maupun pidana ke lembaga peradilan umum, hal ini tentunya akan menyebabkan ketidakpastian hukum dalam penyelesaian sengketa medik tersebut. Meskipun melalui Surat Edaran ( SEMA) Tahun 1982 telah memberikan arahan kepada para hakim untuk menangani kasus dokter atau tenaga kesehatan yang diduga melakukan kesalahan atau kelalaian agar tidak langsung diproses melalui jalur hukum tetapi terlebih dahulu dimintakan pendapat Majelis Kehormatan Etik Kedokteran ( MKEK ) dan /atau Majelis Kehormatan Disiplin Kedokteran Indonesia ( MKDKI ). Ketentuan dalam Pasal 66 ayat 1 Undang Undang Nomor 29 Tahun 2004 yang mengarah pada kesalahan praktik kedokteran " hanya " memberikan dasar hukum untuk melaporkan dokter ke organisasi profesinya dalam hal ini MKDKI bukan sebagai dasar untuk menuntut ganti rugi atas tindakan dokter, sehingga pasal ini dapat dikatakan hanya mempunyai arti dari sudut hukum administrasi saja. Berkaitan dengan hal tersebut maka akibatnya ada beberapa kasus yang ditangani dan diputuskan Majelis kehormatan Disiplin kedokteran Indonesia ( MKDKI ) diajukan ke Pengadilan Tata Usaha Negara karena menganggap bahwa Majelis Kehormatan Disiplin Kedokteran Indonesia dianggap tidak berwenang menangani kasus tersebut.

Hal yang lain berkaitan dengan pengaturan pelayanan praktik dokter sering meninbulkan permasalahan sebagaimana uraian dibawah ini.

a) Dalam keadaan darurat fasilitas pelayanan kesehatan baik pemerintah maupun swasta wajib memberikan pelayanan kesehatan bagi penyelamatan nyawa pasien dan mencegah kecacatan terlebih dahulu, sebagaimana ditegaskan dalam Pasal 32 Undang Undang Nomor 36 Tahun 2009. Demikian juga dalam Pasal 29 Undang Undang Nomor 44 Tahun 2009 menyebutkan bahwa Rumah Sakit wajib memberikan pelayanan gawat darurat kepada pasien sesuai dengan kemampuan pelayanannya. Jadi seharusnya korban kecelakaan yang mengalami keadaan gawat darurat tersebut harus langsung ditangani oleh pihak rumah sakit untuk menyelamatkan nyawanya. Apabila rumah sakit melanggar kewajiban tersebut, maka rumah sakit dikenakan sanksi administratif berupa: a). teguran secara lisan, b). teguran tertulis, c). denda dan pencabutan izin rumah sakit.

Senada dengan hal tersebut sebagaimana diatur dalam Undang-Undang Nomor 36 Tahun 2014 tentang Tenaga Kesehatan khususnya Pasal 59 ayat (1) menyebutkan bahwa tenaga kesehatan yang menjalankan praktik pada fasilitas pelayanan kesehatan wajib memberikan pertolongan pertama kepada penerima pelayanan kesehatan dalam keadaan gawat darurat dan/atau pada bencana untuk penyelamatan nyawa dan pencegahan kecacatan. Demikian pula dalam peraturan Konsil Kedokteran Indonesia Nomor 4 Tahun 2011 tentang Disiplin Profesional Dokter dan Dokter Gigi khususnya Pasal 3 ayat (2) huruf o menyebutkan bahwa pelanggaran disiplin dokter dan dokter gigi salah satunya adalah tidak melakukan pertolongan darurat atas dasar perikemanusiaan. Namun pada kenyataannya pihak rumah sakit sering menolak pasien yang dalam kondiri gawat darurat dengan alasan karena tidak ada alat yang dibutuhkan pasien gawat darurat tersebut atau karena penuhnya kamar perawatan. Sementara untuk pengadaan alat maupun penambahan ruang perawatan tentu dibutuhkan biaya yang tidak sedikit, karena alat-alat kedokteran yang digunakan saat ini kebanyakan merupakan barang impor, sementara itu pemerintah mengenakan pajak yang tinggi terhadap impor alat-alat kedokteran tersebut, hal ini tentunya menimbulkan kesulitan tersendiri bagi rumah sakit untuk dapat memberikan pelayanan yang maksimal kepada pasiennya.

\section{Contoh kasus :}

i. Kasus bayi Dera yang di tolak 8 Rumah Sakit karena tidak tersedianya NICU ( Neonatal Intensive Care Unit). Bayi tersebut terlahir prematur dengan berat badan 1 ( satu ) kilogram dan mengalami gangguan pernafasan. Oleh karena tidak segera mendapatkan perawatan yang dibutuhkan, maka bayi yang baru berumur 5 hari tersebut akhirnya meninggal dunia. Sempat beredar kabar bahwa pihak rumah sakit menolak bayi Dera karena keluarga tidak bisa menyediakan sejumlah uang, meskipun dibantah oleh Menkes pada saat itu, dimana Menkes menyatakan bahwa bayi Dera ditolak rumah sakit karena terbatasnya peralatan.

ii. Okky Oktavianus Elia ( 25 tahun ) pegawai bagian transaksi informasi di Harian Nasional yang di tusuk senjata tajam di pinggang sebelah kanan ketika mempertahankan handphonenya dari penjabret dan kemudian 
oleh temannya dibawa ke rumah sakit. Lima rumah sakit pertama tidak mau menerimanya dengan alasan tidak memiliki alat lengkap. Okky dibawa temannya yang bernama Andi pertama kali ke Rumah Sakit Abdi Waluyo Okky sempat diiberi pertolongan pertama, hanya dibebat perban untuk menahan darah agar tidak keluar tapi perawat menyarankan pindah kerumah sakit besar. Hal yang sama terjadi lagi di RS PGI Cikini, dimana petugas UGD menolaknya setelah mendapat penjelasan pasien adalah korban penusukan, alasan yang dikemukakan karena tidak ada peralatan lengkap. Kemudian di RS Husni Thamrin petugas jaga UGD sempat memeriksa, tapi setelah tahu bahwa itu luka tusukan, petugas tersebut tiba-tiba mengatakan bahwa dokter jaga tidak ada. Selanjutnya Okky dibawa ke Rs Cipto Mangunkusumo, dan disuruh duduk menunggu karena ternyata UGD penuh, karena tidak tega melihat kondisi Okky selanjutnya dia dibawa ke RS Moh Ridwan Meuraksa tapi Okky ditolak dengan alasan Okky bukan pasien peserta BPJS dan akhirnya Okky dibawa ke RS Gatot Subroto, okky diterima di UGD dan langsung diperiksa petugas jaga dan tertangani setelah ada 5 rumah sakit yang menolaknya.

b) Pengaturan pasal 41 ayat 1 UU No 29 Tahun 2004 yo pasal 26 ayat 1 Permenkes No 2052/Menkes/Per/X/2011 dengan pasal 4 ayat 1 Permenkes Nomor 2052/Menkes/Per/X/2011. Pasal 41 ayat 1 UU No 29 Tahun 2004, dokter atau dokter gigi yang telah mempunyai surat izin praktik dan menyelenggarakan praktik kedokteran, wajib memasang papan nama praktik kedokterannya, demikian pula dalam pasal 26 ayat 1 Permenkes No 2052/Menkes/Per/X/2011, dokter dan dokter gigi yang telah memiliki SIP dan menyelenggarakan praktik perorangan wajib memasang papan nama praktik kedokteran. Dalam papan nama praktik dokter tersebut tentunya tertera jadwal jam praktek dokter tersebut namun seringkali dokter mengingkari jam praktik yang tertera dalam papan nama tersebut seperti dokter datang terlambat dari jadwal jam praktik dengan alasan masih berpraktik di tempat lain, karena dokter mendapatkan 3 (tiga) tempat praktik baik pada fasilitas pelayanan kesehatan milik pemerintah, swasta, maupun praktik perorangan(Pasal 4 ayat 1 Permenkes Nomor 2052/Menkes/Per/X/2011) atau bahkan sama sekali tidak datang tanpa ada pemberitahuan terlebih dahulu. Pengaturan pasal 4 ayat 1 Permenkes tersebut berpotensi menimbulkan kerugian pada pihak pasien berkaitan dengan ketepatan waktu untuk mendapatkan perawatan yang bisa berakibat fatal bagi penyelamatan nyawa pasien.

\section{Contoh kasus :}

Seorang ibu yang akan melahirkan anak pertamanya di Rumah Bersalin Ikatan Bidan di Bali, dimana aktifitas rumah bersalin tersebut dibawah pengawasan seorang dokter namun sayangnya pada saat si ibu datang, dokter pengawas tidak berada di tempat, sehingga pemeriksaan awal menjelang persalinan itu dilakukan oleh bidan yang bertugas. Setelah bidan memeriksa detak jantung bayi dan memberi petunjuk tentang cara bernafas saat akan melahirkan ternyata di depan rumah bersalin tersebut ada kecelakaan dan bidan meninggalkan si ibu. Bidan tersebutbaru kembali setelah beberapa lama, kemudian melakukan pemecahan ketuban, namun saat ketuban pecah bidan merasa bingung dan panik dan menganjurkan kepada suami si ibu untuk segera membawa istrinya ke RSUP Sanglah Denpasar. Setiba di RSUP Sanglah si ibu segera ditangani tim medis dan si ibu melahirkan bayi tetapi dalam kondisi meninggal. Keterangan pihak RSUP menyatakan bahwa bayi meninggal karena prolaps tali pusat dan kematian sudah dalam kandungan, karena bidan tidak serius dan hati-hati dalam menangani pasien. Dalam hal ini yang bertanggung jawab adalah bidan dan pimpinan rumah bersalin tersebut.

c) Ketentuan Pasal 3 huruf a Undang-Undang Nomor 44 Tahun 2009 yang menyebutkan bahwa penyelenggaraan rumah sakit bertujuan untuk mempermudah akses masyarakat dalam mendapatkan pelayanan kesehatan. Berkaitan dengan kemudahan akses masyarakat untuk mendapatkan pelayanan kesehatan ini ternyata bagi sebagian masyarakat belum dapat diperoleh secara mudah terlebih untuk pasien yang mempergunakan kartu jaminan kesehatan, hal itu disebabkan karena ternyata tidak semua rumah sakit melakukan kerjasama dengan pemerintah berkaitan dengan kartu jaminan kesehatan. Padahal seperti yang dicanangkan pemerintah bahwa mulai 1 Januari 2014 masyarakat wajib menjadi anggota BPJS kesehatan ( pasal 14 UU BPJS )

\section{Contoh kasus :}

Kasus penolakan pasien dalam pelayanan kesehatan yang terjadi di Lampung, menimpa Akbar Abdul Majid ( 20 tahun ) mahasiswa Universitas Malahayati Bandar Lampung yang ditolak Rumah Sakit Immanuel karena hendak menggunakan pelayanan kesehatan dengan kartu BPJS, pasien tersebut dalam kondisi kritis karena mengalami kecelakaan motor. Salah satu keluarga Akbar menyatakan bahwa dia sempat dibawa ke Rumah Sakit Islam Natar, tapi karena peralatan tak memadai, akhirnya dirujuk ke RSUD Abdoel Moeloek ( RSUDAM) Bandar Lampung. Setibanya di RSUDAM ternyata ruang Intensif Care Unit ( ICU ) penuh, karena Akbar membutuhkan perawatan serius, akhirnya pihak RSUDAM merujuk ke RS Immanuel. Setibanya di RS Immanuel, Akbar yang sudah kritis ditolak perawat penjaga Unit Gawat darurat ( UGD ) RS setempat denganalasanRumah Sakit Imanuel tidak melayani pasien yang menggunakan BPJS. Akhirnya setelah menunggu beberapa jam RSUDAM mengabarkan bahwa ruang ICU di rumah sakit tersebut sudah tersedia dan pasien Akbar ditangani di Rumah Sakit Umum Daerah Abdoel Moeloek. ${ }^{16}$

\footnotetext{
${ }^{16}$ Harian Lampung.com, , tanggal 25 Januari 2015, jam 21.00, diakses tanggal 1Maret 2015 jam 20.00
} 
Website : http://yustisia.unmermadiun.ac.id/index.php/yustisia

\section{III.PENUTUP}

\section{A. Kesimpulan}

Hubungan hukum dalam pelayanan kesehatan merupakan hubungan hukum yang saling kait mengkait antara pemberi layanan kesehatan ( health provider ) dan penerima layanan kesehatan (health receiver), dimana hubungan tersebut akan menimbulkan suatu transaksi yang disebut dengan transaksi terapeutik. Transaksi terapeutik ini menimbulkan hak dan kewajiban diantara para pihak sebagaimana diatur dalam Undang Undang Nomer 29 Tahun 2004 tentang Praktik Kedokteran, Undang Undang Nomer 36 Tahun 2009 tentang Kesehatan, Undang Undang Nomer 44 Tahun 2009 tentang Rumah Sakit. Transaksi terapeutik ini sebagai landasan pemberian persetujuan tindakan medis (informed consent), karena informed consent merupakan hak atas informasi seorang pasien. Pengaturan hak dan kewajiban dimana salah satunya adalah adanya persetujuan tindakan medis, secara yuridis dimaksudkan untuk memberikan perlindungan yang seimbang dan objektif baik terhadap dokter maupun masyarakat. Namun ternyata saat ini perlindungan yang diharapkan tersebut belum dapat dirasakan oleh pasien. Adapun faktor-faktor yang menyebabkan transaksi terapeutik saat ini belum memberi perlindungan kepada pasien menyangkut pelaksanaan sistem dalam pelayanan kesehatan yaitu, bahwa secara substansi masih terdapat peraturan yang berbenturan dengan etika, disiplin, maupun hukum. berkaitan dengan fungsi dan kewenangan kelembagaan bahwa lembaga-lembaga yang dibentuk sebagai upaya perlindungan ternyata belum menunjukkan objektifitasnya pada saat menangani kasus-kasus sengketa medis karena hanya berorientasi pada kesejawatan saja. Demikian pula dengan faktor budaya atau kultur masyarakat yang cenderung pasif serta permisif mensikapi permasalahan-permasalahan yang muncul dalam hubungan antara dokter dan pasiennya pada pelayanan kesehatan.

\section{B. Saran}

Transaksi terapeutik wajib dijadikan bagian dalam kurikulum sistem pendidikan kedokteran di Indonesia. Dokter yang menjalankan praktik kedokterannya harus berpedoman pada norma-norma etik, disiplin maupun hukum. Norma etik berkaitan dengan perilaku dokter yang harus sesuai dengan kode etik profesinya maupun sumpah kedokteran sebagaimana tertuang dalam sumpah Hippocrates yang sampai saat ini masih menjadi landasan etik seorang dokter. Sedangkan disiplin berkaitan dengan ilmu pengetahuan yang ditekuninya yang menjadikan seorang dokter berkompeten di bidang ilmu kedokteran serta norma hukum yang berkaitan dengan posisinya sebagai subjek hukum pengemban hak dan kewajiban yang harus dapat dipertanggungjawabkan secara hukum, baik hukum perdata, hukum pidana, maupun hukum administrasi Negara.

\section{IV.DAFTAR PUSTAKA}

Amri Amir, 1997, Bunga Rampai Hukum Kesehatan, Jakarta : Widya Medika

Abdulrahman, 1987, Tebaran Pikiran Tentang Strudi Hukum dan Masyarakat,Jakarta : Media Sarana Press 1989, Perkembangan Pemikiran tentang Pembinaan Hukum Nasional di Indonesia,Jakarta : Akademika Pressindo

Albert R. Jonsen,2000, A Short History of Medical Ethics, School of Medicine University of Washington, New York : Oxford University Press

Ahmadi Miru,2004, Prinsi-Prinsip Perlindungan Hukum Bagi Konsumen di Indonesia, Disertasi, Program Pascasarjana Universitas Airlangga, Surabaya, tidak diterbitkan

Ameln, Fred, 1991, Kapita Selekta Hukum Kedokteran, Jakarta : Grafikatama Jaya

Appelbaum, Paul Charles and Alan Huseil, 1987, Informed Consent Legal Theory and Clinical Practice, New York: Oxford University Press

Abdulkadir Muhamad, 2006, Etika Profesi Hukum, Bandung : Citra Aditya Bakti

Crisdiono M Achadiat, 2007, Dinamika dan Etika Kedokteran Dalam Tantangan Zaman,Jakarta : Buku Kedokteran ECG.

Cahyono, JB. Suharyo B, 2011, Mengungkap Kekuatan Penyembuhan Diri yang Tidak terbatas, Jakarta : Gramedia 2008, Membangun Budaya keselamatan Pasien dalam Praktik kedokteran, Yogjakarta : Kanisius

Eka Julianta Wahjoepramono, 2012, Konsekwensi Hukum Dalam Profesi Medik, Bandung: Karya Putra Darwati.

Fredy Tengker, 2007, Hak Pasien, Bandung: Mandar Maju

Guwadi,, 2008, Hukum dan Dokter, Jakarta: Sagung Seto

Hermien Hadiati, 1998, Hukum Kedokteran : Studi tentang Hubungan Hukum Dalam Mana Dokter Sebagai Salah satu Pihak, Bandung: PT Citra Aditya Bakti. Hendrojono Soewono, 2006, Perlindungan Hak-hak Pasien dalam Transaksi Terapeutik, Suatu Tinjauan Yuridis Setelah Berlakunya Undang-Undang Nomor 29 Tahun 2004 Tentang Praktek Kedokteran, Surabaya : Srikandi, Surabaya.

2005, Batas Pertanggungjawaban Hukum Malpraktek Dokter dalam Transaksi Terapeutik, Surabaya : Srikandi

Jhon Rawls,1995. A Theory Of Justice, Cambridge Harvard University Press,( edisi terjemahan oleh Uzair Fausan dan Heru Prasetyo.2011. Teori Keadilan Dasar-Dasar Filsafat Politik untuk Mewujudkan Kesejahteraan Sosial Dalam Negara, Yogyakarta : Pustaka Pelajar)

M. Jusuf Hanafiah dan Amri Amir,2009, Etika Kedokteran dan Hukum Kesehatan Ed.4, Jakarta : Penerbit Buku Kedokteran ECG

Munir Fuady, 2005, Sumpah Hippocrates : Aspek Hukum Malpraktek Dokter, Bandung : Citra Aditya Bakti

Sudikno Mertokusumo, 1996, Mengenal Hukum (Suatu Pengantar), Yogyakarta: Liberty

Safitri Hariyani, 2005, Sengketa Medik Alternatif Penyelesaian Perselisihan Antara Dokter Dengan Pasien, Jakarta: Diadit Media

Syahrul Machmud, 2008, Penegakan Hukum dan Perlindungan Hukum Bagi Dokter Yang Diduga Melakukan Medikal Malpraktek, Bandung:Penerbit Mandar Maju

Titon Slamet Kurnia, 2007, Hak Atas Derajat Kesehatan Optimal Sebagai HAM di Indonesia, Bandung : PT Alumni 